\title{
Kelp beds as habitat for American lobster Homarus americanus
}

\author{
Paul A. X. Bologna*, Robert S. Steneck \\ Department of Oceanography, University of Maine, Darling Marine Center, Walpole, Maine 04573, USA
}

\begin{abstract}
The American lobster Homarus americanus and kelp Laminaria longicruris and $L$. saccharina are prominent and often intimately associated members of the subtidal community in the western North Atlantic Ocean. However, no one has identified the nature of this relationship or specifically investigated whether kelp beds are a superior habitat for lobsters. We conducted field studies in 1990 and 1991 at a coastal site centrally located along the Gulf of Maine, USA, to determine how lobsters use kelp beds as habitat. Identically sized and spaced plots of live and artificial (plastic) kelp were established and monitored for lobster population densities. Adjacent featureless sediment plots of identical size served as controls. Lobster population density and biomass were significantly higher in both real and artificial kelp treatments than in non-kelp control plots $(p<0.0001)$. The change in lobster density was apparent the day following placement of the experiment, so a secondary trophic effect such as attracting prey into treatments is unlikely to have occurred. Thus, kelp beds can affect local lobster population densities by providing shelter for lobsters, thereby concentrating individuals and increasing the local carrying capacity of potential lobster habitats. The effect of kelp beds on the local carrying capacity of lobster habitats was further explored by testing how lobsters respond to differing patch sizes. A graded size series of circular patches of artificial kelp was established, in which kelp blade density and total area were held constant for each treatment. Treatments were subdivided into four $1 \mathrm{~m}^{2}$, two $2 \mathrm{~m}^{2}$, or one $4 \mathrm{~m}^{2}$ patches. Experiments were surveyed for lobster population density and size structure to determine if statistical differences existed among treatments. Lobster density was significantly greater in the smallest patches $(p<0.001)$. Moreover, lobsters typically occupied the edges of kelp beds, and their abundance within kelp patches corresponded to the patch's perimeter-to-area relationship. This suggests that 'edge effects' influence the local carrying capacity for lobsters by influencing the lobsters' choice of kelp beds as habitat.
\end{abstract}

\section{INTRODUCTION}

The 3-dimensional arrangement of physical structures has important implications for species living in aquatic communities. Habitat architecture has been shown to influence local diversity (Littler et al. 1983), body size (Hacker \& Steneck 1990), recruitment (Connell \& Jones 1991), population size structure (Howard 1980) and survival (Heck \& Thoman 1981) of species in marine communities. The American lobster Homarus americanus is often associated with structurally complex habitats. Specifically, local lobster population

\footnotetext{
- Present address: Dept of Marine Sciences, University of South Alabama, Dauphin Island Sea Lab., PO Box 369-370, Dauphin Island, Alabama 36528, USA
}

density may correspond directly with the availability of physical shelters (Cobb 1971, Cooper \& Uzmann 1980, Wahle \& Steneck 1991).

Structural habitats may be formed by both biotic (e.g. coral reefs and kelp forests) and abiotic (rock, metal, and concrete) elements (Bodkin 1988). Biotic components of a structural habitat are often the major source of spatial heterogeneity in communities (Stoner \& Lewis 1985 , Hacker \& Steneck 1990). The higher abundances and diversities of species in coral reefs (Luckhurst \& Luckhurst 1978), sea grass stands (Kikuchi 1980), and kelp forests (Carr 1989) correlate with the presence of these structures. Unlike coral or rock habitats, plants create relatively ephemeral structures, that if disturbed can result in changes in the associated floral community (Sousa 1979, Cowen et al. 1982) and animal populations 
dependent upon them (Rasmussen 1973, Heck \& Orth 1980, Heck \& Thoman 1981).

Marine plants influence communities by providing both primary production and increased structural complexity to the habitat. For seagrass communities, Stoner \& Lewis (1985) showed that both quantitative (i.e. biomass) and qualitative (3-dimensional structure) aspects of the habitat influence the density and diversity of the fauna. Similar changes in habitat structure that correspond to changes in species composition have also been shown for kelp communities (Ebeling \& Laur 1985, Carr 1989, DeMartini \& Roberts 1990).

Grazing by sea urchins influences the structure of algal communities and thereby alters the distribution and abundance of the biogenic habitat for associated species (Chapman 1981, Bernstein \& Mann 1982, Scheibling 1986). When urchin populations are large, kelp forests decline (Paine \& Vadas 1969, Mann 1977. Hagen 1983), and this loss of habitat can have drastic consequences for associated members of the community (Allen \& Griffiths 1981, Bodkin 1988).

The American lobster Homarus americanus has been associated with the abundance of kelp (Wharton \& Mann 1981, Hudon 1987). However, this association may be confounded by other factors such as the availability of boulder shelters (e.g. Hudon \& Lamarche 1989). Although some have questioned the validity of this association (Miller 1989), no one has experimentally tested it. It is also unknown if the arrangement, size, and distribution of kelp beds in a region influence the abundance and distribution of lobsters. If a positive

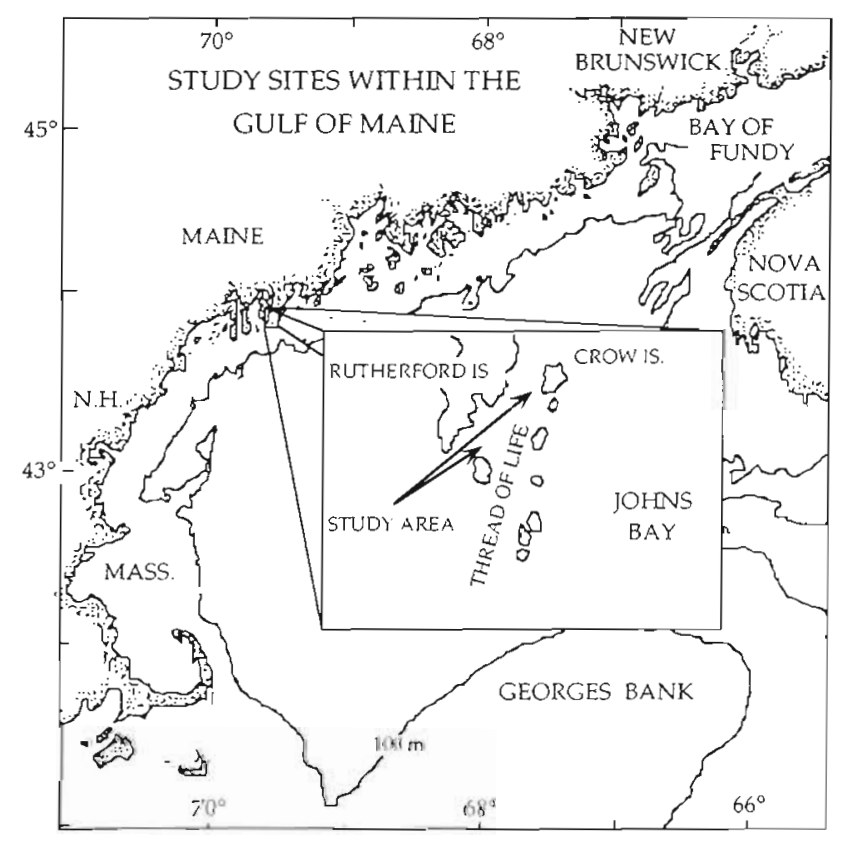

Fig. 1. Study sites association between lobsters and kelp exists, is it due to increases in spatial heterogeneity or to increases in associated trophic resources? This study provides quantitative, experimental results showing that $H$. americanus uses kelp beds as shelter and that the size and shape of these beds can influence the local carrying capacity for lobsters.

\section{MATERIALS AND METHODS}

Study site. Research was conducted in an area called the Thread of Life which is located between Rutherford Island and several small islands including Crow Island, Maine, USA (Fig. 1). This site is centrally located along the coast of the Gulf of Maine and was chosen for its accessibility and abundant lobster population. It is typified by shallow, subtidal hard substrata provided by the islands, grading into boulders and finally featureless sediment at the channel's maximum depth of 10 to $20 \mathrm{~m}$. The deeper hard substratum is dominated by an urchin-coralline community, while in shallower areas, fleshy macrophytes (i.e. kelp) increase in abundance. Water temperatures at this site range from 2 to $3^{\circ} \mathrm{C}$ in winter to 15 to $16^{\circ} \mathrm{C}$ during the summer. Beginning in late spring and lasting through early fall the region is commercially fished for lobsters.

Kelp as habitat. Natural populations of Laminaria longicruris and L. saccharina (hereafter referred to as Laminaria spp.) were sampled in the spring of 1990. Morphometric data on the population structure of Laminaria spp. were collected from the west side of Crow Island (Fig. 1). Using SCUBA, $0.25 \mathrm{~m}^{2}$ quadrats were tossed haphazardly into kelp beds having a complete cover of Laminaria spp. Stipe length, frond length, and frond width were recorded for all Laminaria spp. in each quadrat. Population density and morphometric data from 28 samples taken in the summer were used to design experimental kelp beds. It was determined that only kelp $>50 \mathrm{~cm}$ total length would be used in experimental manipulations, because only large kelp were commonly observed sheltering lobsters.

Experimental kelp beds and control plots were established on relatively featureless silty-sand substrata ('sediment flats'). Sediment flats had low lobster densities and were amenable to the field manipulations in these experiments. Although natural kelp was found throughout this region growing on scattered hard substrata in the featureless sediment, extensive kelp beds do not naturally occur here. Since our aim was to isolate and examine the role of kelp cover alone, we chose to conduct our experiments in this habitat. This was the most desirable habitat available to us, because most rock substrata had numerous shelter spaces between 
boulders or in crevices or had complex sloping orientation which made replication difficult. Additionally, to determine whether lobsters use kelp as a shelter habitat or whether they were attracted to kelp for possible trophic resources, artificial kelp treatments were used. Artificial kelp treatments eliminated the possibility that kelp provided organic attractants for lobsters.

Kelp experimental plots were created using the mean Laminaria spp. plant density of 13 plants $\mathrm{m}^{-2}$ (Table 1 ) in subtidal regions 10 to $15 \mathrm{~m}$ deep. Laminaria spp. were collected from nearby kelp beds and all plants used for experiments were within $1 \mathrm{SD}$ of the mean size of natural Laminaria spp. (see large kelp, Table 1). Laminaria spp. holdfasts were attached with plastic cable-ties to $15 \mathrm{~cm}$ long pieces of $0.95 \mathrm{~cm}$ solid steel bar and anchored in experimental plots laid out on the sediment. Artificial kelp were constructed to resemble live Laminaria spp. in most physical attributes, but they had no nutritional value. The average size of large kelp was used as a guide for artificial kelp. Kelp had stipe lengths of $17 \mathrm{~cm}$, frond lengths of $133 \mathrm{~cm}$, and frond widths of $27 \mathrm{~cm}$ (see Table 1). Artificial kelp fronds were cut from $102 \mu \mathrm{m}$ black construction-grade plastic. Lead flashing was glued to the fronds to negate the plastic's positive buoyancy and thus better mimic live kelp (method suggested by D. O. Duggins pers. comm.). Fronds were attached with cable-ties to artificial stipes made of $1.27 \mathrm{~cm}$ diameter polypropylene line and the stipes were fastened to $15 \mathrm{~cm}$ long pieces of $0.95 \mathrm{~cm}$ solid steel bar in order to anchor them into the sediment. Control regions adjacent to experimental plots were also established. Using a random number table, 5 spatial replicates of each treatment were established at locations along a preset transect at a water depth of 10 to $15 \mathrm{~m}$ in the Thread of Life. Plots were laid out linearly to reduce potential interactions and were at least $5 \mathrm{~m}$ apart from one another. All plots were 20 to $40 \mathrm{~m}$ away from a high carrying-capacity lobster habitat (e.g. boulder/cobble substrata).

Plots were surveyed by divers on 17 days between August and October 1990. Carapace length (CL), sex, and number of chelae were recorded for all lobsters

Table 1. Natural kelp population demographics $\left(\mathrm{n}=28 ; 0.25 \mathrm{~m}^{2}\right.$ quadrats). Lengths and width in $\mathrm{cm}$ ( $\pm 1 \mathrm{SD})$. Kelp density: number of Laminaria longicruris and L. saccharina $\mathrm{m}^{-2}( \pm 1 \mathrm{SD})$

\begin{tabular}{|lrr|}
\hline Algal structure & All kelp & \multicolumn{1}{c|}{$\begin{array}{c}\text { Large kelp } \\
(>50 \mathrm{~cm})\end{array}$} \\
\hline Total length & $57.7 \pm 75.8$ & $149.5 \pm 75.5$ \\
Stipe length & $7.6 \pm 9.7$ & $16.8 \pm 12.2$ \\
Frond length & $50.1 \pm 69.6$ & $132.7 \pm 72.9$ \\
Frond width & $11.9 \pm 11.8$ & $26.8 \pm 9.6$ \\
Kelp density & $40.6 \pm 30.7$ & $12.7 \pm 11.0$ \\
\hline
\end{tabular}

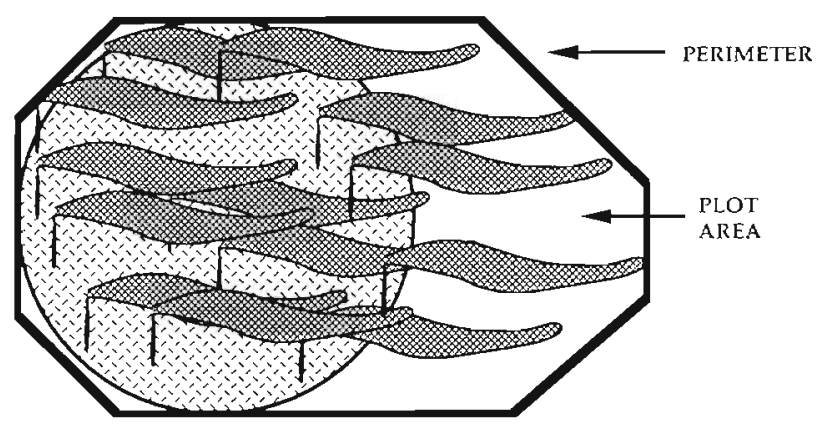

Fig. 2. Schematic drawing of an artificial kelp treatment. Circular region depicts the area where artificial stipes were planted. Solid border surrounding the patch indicates the minimum perimeter associated with the plot and the total area covered by the kelp

throughout the experiment. Average lobster biomass was calculated using Thomas' (1973) equation: total weight $(W)=0.00168 \mathrm{CL}^{2.828}$. Because this relationship is based on lobsters possessing both chelae, it was modified to reflect the average number of chelae of lobsters in treatments. This was done by taking the average number of chelae and dividing by 2 (total possible number of chelae) and then multiplying by $W$ to give a corrected individual biomass [ $W=$ (av. no. of chelae /2) $\left.\left(0.00168 \mathrm{CL}^{2.828}\right)\right]$. All lobsters were removed from experimental and control plots at the time of each survey to ensure independent sampling. Lobster density and population demography were determined and compared between treatments using ANOVA

Influences of kelp patch size. To test the hypothesis that lobsters seek edges of kelp beds, experiments were conducted that held total kelp bed area constant, but varied the perimeter length. This was done by establishing treatments of one $4 \mathrm{~m}^{2}$, two $2 \mathrm{~m}^{2}$, and four $1 \mathrm{~m}^{2}$ circular kelp-bed patches. Since each treatment occupied the same total area (area in which stipes were planted), only perimeters varied. Since fronds draped beyond the area in which kelp were planted, total kelp-bed area and perimeter were measured in situ. Four kelp-bed diameter measurements were taken $45^{\circ}$ from one another, creating an octagon subdivided into 8 triangles. These were used for minimum area and perimeter analysis (see Fig 2). Experimental plots of the $4 \mathrm{~m}^{2}, 2 \mathrm{~m}^{2}$, and $1 \mathrm{~m}^{2}$ treatments were measured during different tidal regimes so the average lay of fronds could be assessed, in order to determine the total area of frond coverage and associated perimeter of treatments (Table 2). Artificial kelp were constructed in the same manner as before, using the natural morphometrics and density of local Laminaria spp. beds (see Table 1). Three spatial replicates of experimental treatments were planted 8 to $15 \mathrm{~m}$ deep within the study area in the Thread of Life (Fig. 1). 
Table 2. Analysis of experimental kelp bed perimeter and area by treatments. Base area indicates the area containing planted kelp stipes. Total plot area is the average total kelp-covered area $\left(\mathrm{m}^{2} \pm 1 \mathrm{SD}\right)$ of an experimental treatment. Total perimeter is the average total perimeter ( $\mathrm{m} \pm 1 \mathrm{SD}$ ) associated with a given experimental treatment calculated by minimum perimeter analysis (see Fig. 2)

\begin{tabular}{ccccrc|}
\hline $\begin{array}{c}\text { Treatment } \\
\left(\mathrm{m}^{2}\right)\end{array}$ & $\mathrm{N}$ & $\begin{array}{c}\text { Base area } \\
\left(\mathrm{m}^{2}\right)\end{array}$ & $\begin{array}{c}\text { Total area } \\
\left(\mathrm{m}^{2}\right)\end{array}$ & $\begin{array}{c}\text { Total perimeter } \\
(\mathrm{m})\end{array}$ & $\begin{array}{c}\text { Perimeter : area } \\
\text { relationship }\end{array}$ \\
\hline 1 & 13 & 4.0 & $6.63 \pm 0.32$ & $18.35 \pm 2.22$ & 2.77 \\
2 & 10 & 4.0 & $6.91 \pm 0.64$ & $12.76 \pm 1.29$ & 1.85 \\
4 & 7 & 4.0 & $6.30 \pm 0.68$ & $8.52 \pm 0.38$ & 1.35 \\
\hline
\end{tabular}

Table 3. Homarus americanus. Lobster population demography for experimental treatments. N: number of replicate samples of each treatment. Density: number of lobsters $\mathrm{m}^{-2} \pm 1 \mathrm{SD}$. Lobster size: average carapace length (CL, $\mathrm{mm} \pm 1 \mathrm{SD}$ ); values in parentheses indicate numbers of individuals in the sample. Sex ratio expressed as numbers of males: number of females. Biomass calculated into live weight ( $\mathrm{g}$ ) using Thomas' (1973) equation $W=0.00168 \mathrm{CL}^{2.828}$, modified to reflect the average number of chelae (see 'Methods')

\begin{tabular}{|c|c|c|c|c|c|}
\hline Treatment & $\mathrm{N}$ & Density (ind. $\mathrm{m}^{-2}$ ) & $\mathrm{CL}(\mathrm{mm})$ & Sex ratio & Biomass $\left(\mathrm{g} \mathrm{m}^{-2}\right)$ \\
\hline \multicolumn{6}{|c|}{1990 lobster population } \\
\hline Control & 85 & $0.14 \pm 0.35$ & $60.5 \pm 9.9(12)$ & 1.40 & $23.9 \pm 10.3$ \\
\hline Laminaria spp. & 85 & $1.59 \pm 0.86$ & $52.7 \pm 14.9(134)$ & 1.16 & $202.0 \pm 144.2$ \\
\hline Artificial kelp & 85 & $1.68 \pm 0.99$ & $52.9 \pm 15.8(142)$ & 1.03 & $223.3 \pm 167.9$ \\
\hline Total & 255 & & $53.1 \pm 15.3(290)$ & 1.1 & \\
\hline \multicolumn{6}{|c|}{1991 lobster population } \\
\hline $1 \mathrm{~m}^{2}$ & 48 & $1.65 \pm 0.66$ & $50.5 \pm 15.7 \quad(617)$ & 1.07 & $199.3 \pm 156.8$ \\
\hline $2 \mathrm{~m}^{2}$ & 48 & $1.41 \pm 0.51$ & $51.0 \pm 15.7 \quad(474)$ & 1.07 & $167.8 \pm 131.1$ \\
\hline $4 \mathrm{~m}^{2}$ & 48 & $1.20 \pm 0.56$ & $50.5 \pm 15.0$ & 1.06 & $143.8 \pm 111.3$ \\
\hline Total & 144 & & $50.7 \pm 15.6(1423)$ & 1.07 & \\
\hline
\end{tabular}

Surveys of experimental treatments were conducted on 16 days between July and September 1991. CL, sex, and number of chelae were recorded for each lobster throughout the experiment. Average biomass was calculated using the modified Thomas (1973) equation.

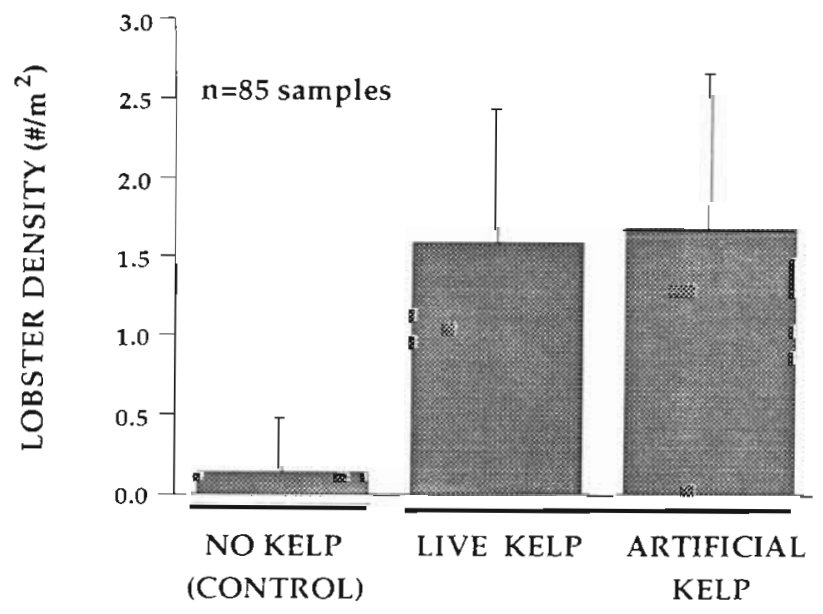

Fig. 3. Average lobster density (ind $\mathrm{m}^{-2} \pm 1 \mathrm{SD}$ ) for 1990 experimental treatments. Line breaks indicate significant differences $(p<0.0001)$ for 1 -way ANOVA among treatments
All lobsters were removed from treatments at the time of surveys to ensure independent sampling. Lobster density was compared among the 3 treatments using 1 -way ANOVA. Spatial replicates were also analyzed to determine if differences existed between them. Two-way ANOVA was used to compare lobster densities between treatments and replicates. A KruskalWallis test was calculated from the lobster size distribution data to determine whether differences existed in the lobster populations among treatments. This was done to determine whether changes in lobster density corresponded to changes in the lobster subpopulation utilizing a particular patch size.

\section{RESULTS}

\section{Kelp beds as habitat}

Lobster population density and biomass inside transplanted Laminaria spp. beds were significantly higher than in control regions (Table 3). Lobsters did not burrow into the sediment, but sought shelter beneath the kelp. No difference in lobster density was observed between live Laminaria spp. and artificial kelp treatments (Fig. 3), but both treatments main- 


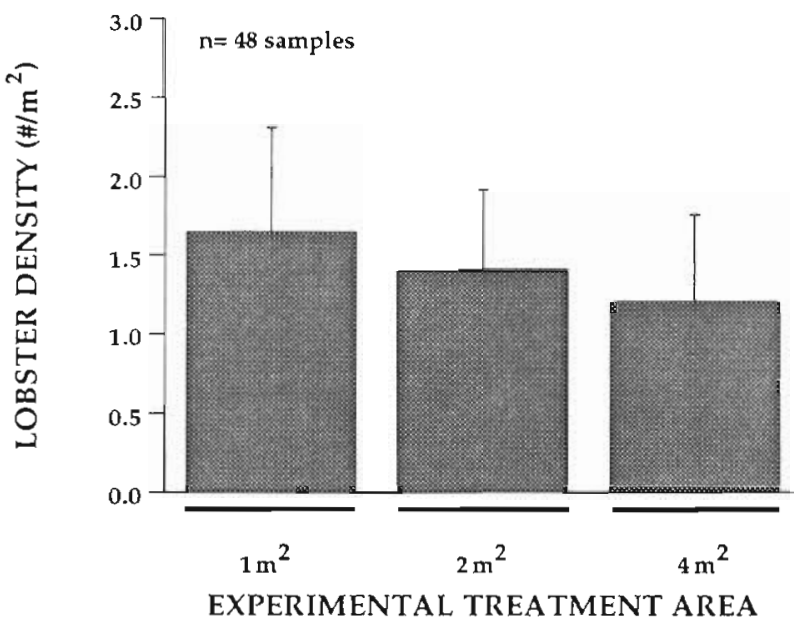

Fig. 4. Average lobster density (ind. $\mathrm{m}^{-2} \pm 1 \mathrm{SD}$ ) for 1991 experimental kelp patch treatments. Line breaks indicate significant differences $(p<0.001)$ for 1 -way ANOVA among treatments

tained lobster densities and biomasses that were an order of magnitude greater than adjacent control regions (ANOVA: $\mathrm{p}<0.0001$ ). Kruskal-Wallis analysis showed no difference in lobster size among treatments $(p>0.5)$ indicating a common pool of lobsters colonizing treatments.

Lobsters responded rapidly to the planting of artificial kelp and were observed in artificial kelp plots the day following placement. It is highly unlikely that lobsters were seeking trophic benefits in these patches, because invertebrate prey were not observed, nor was there time for 'epiphytes' to settle onto the fronds and attract lobsters or their prey. During the length of the experiment, artificial kelp fronds did not accumulate much epiphytic settlement and growth, nor was there an influx of mobile prey (e.g. crabs, urchins) into the plots. The continued use of artificial kelp by lobsters indicates that the physical structure created by the

Table 4. 1991 experimental treatment statistical summary showing results of a 2-way ANOVA of lobster density by treatment and site

\begin{tabular}{|lrrrrr|}
\hline Source & SS & df & MS & F-ratio & p > F \\
\hline $\begin{array}{l}\text { Between } \\
\text { replicates }\end{array}$ & 10.579 & 2 & 5.289 & 19.587 & 0.001 \\
$\begin{array}{l}\text { Between } \\
\text { treatments }\end{array}$ & 4.714 & 2 & 2.357 & 8.729 & 0.001 \\
Interaction & 1.103 & 4 & 0.276 & 1.021 & 0.399 \\
Error & 36.457 & 135 & 0.270 & & \\
Total & 52.854 & 143 & & & \\
\hline
\end{tabular}

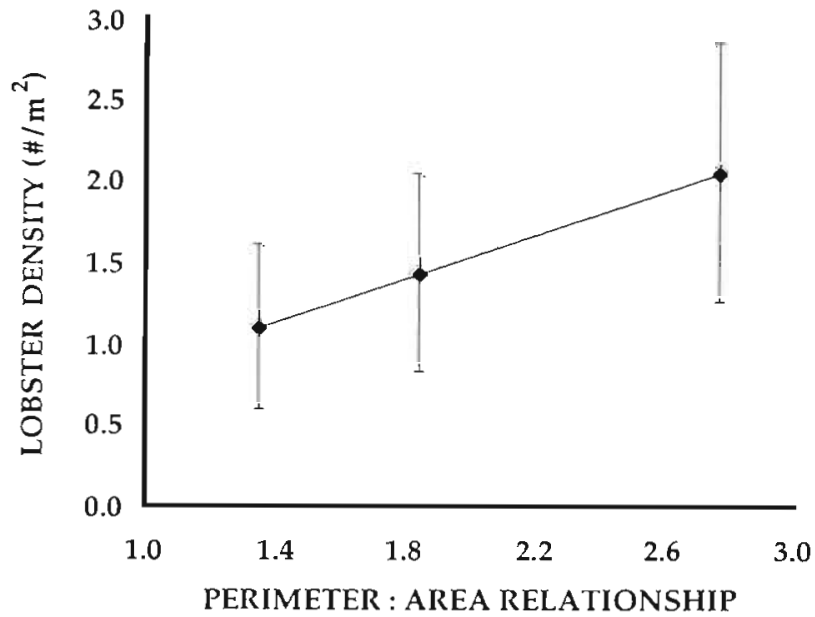

Fig. 5. Correlation between lobster density (ind. $\mathrm{m}^{-2} \pm 1 \mathrm{SD}$ ) and perimeter-to-area relationships for experimental treatments $(y=0.1897+0.6713 x ; \mathrm{R}=0.99)$. Perimeter-to-area relationship is the mean total perimeter divided by the mean total area of a treatment (see Table 2)

kelp bed, rather than the associated trophic interactions, is what influenced the lobsters' choice of kelp as a habitat.

\section{Influence of kelp patch size and perimeter on lobster abundance}

Experiments with artificial kelp patches indicated that as patch area increased, lobster density decreased significantly (Fig. 4). Although differences in absolute lobster density existed between replicates, the pattern of increasing patch size with decreasing lobster density was consistent (Table 4 ). Lobster size (CL) and sex ratios were not significantly different among the treatments (Kruskal-Wallis: $p \geq 0.5$ ).

Lobsters were most frequently encountered along edges of experimental patches during kelp bed surveys (Bologna pers. obs.), and lobster density corresponded positively with the perimeter-to-area relationship (Table 2) for all treatments (Fig. 5). This indicates that changes in the perimeter-to-area relationship of kelp patches (i.e. how kelp beds are subdivided) may influence the abundance of lobsters seeking shelter in a patch. To assess the importance of kelp bed edges, perimeter was isolated as an indicator of edge and plotted against lobster abundance for each treatment (Fig. 6). No significant differences were observed in lobster abundance when considered per length of perimeter. Thus, perimeter length of a kelp bed may be an important determinant of the positive influence kelp beds play in setting the local carrying capacity for lobsters. These results suggest that with increasing 


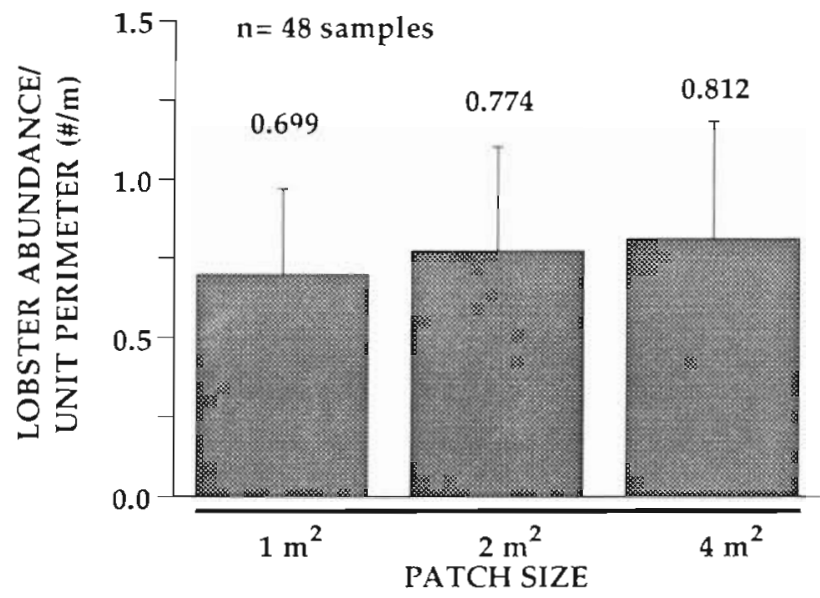

Fig. 6. A posteriori ANOVA results of the relationship between lobster abundance/treatment perimeter (number of lobsters per unit perimeter) and experimental patch size. Continuous line under treatments indicates no significant difference among them

kelp bed size, the relative importance of this positive edge effect on the local carrying capacity for lobsters will decline.

\section{DISCUSSION}

Our results demonstrate experimentally that kelp beds have a positive effect on local lobster population density. These kelp beds concentrated lobsters in featureless areas where their population density would otherwise be low. In the coastal waters of Maine, only the smallest early benthic phase lobsters $(5$ to $25 \mathrm{~mm}$ CL) require shelter for protection from predators (Wahle \& Steneck 1992, Steneck unpubl. data), however lobsters may seek kelp beds for 'expected' trophic resources or as a result of thigmotactic or light-avoidance behavior. Our study has shown that lobster density was an order of magnitude greater within experimental kelp beds relative to adjacent sandy control regions. When artificial kelp were included in experiments, the same pattern of habitat use was evident with respect to controls, but lobster density did not differ significantly from Laminaria spp. beds (Fig. 3, Table 3). The immediate response of lobsters seeking shelter under artificial kelp (which provided no immediate trophic benefits) along with the significant difference in lobster density $(p<0.001)$ indicate that the structural characteristic of the kelp habitat seems to be the principal attracting force for lobsters.

Habitat architecture refers to the distribution, abundance and arrangement of habitable spaces (sensu Hacker \& Steneck 1990). It has been shown to influ- ence the recruitment (Marx \& Herrnkind 1985, Herrnkind \& Butler 1986), colonization (Virnstein \& Curran 1986), body size (Schneider \& Mann 1991) and population size structure (Howard 1980) for numerous crustaceans. Because kelp beds are used as a habitat by lobsters, the size and arrangement of kelp beds in a region should influence lobsters' use of kelp as a habitat. In the graded size series of circular experimental kelp bed treatments, lobster population density and body size were used to determine if lobsters showed a preference for a particular kelp patch size. As experimental treatment patch area increased, lobster density decreased significantly ( $p<0.001)$. These results indicate that the amount of kelp bed perimeter (i.e. arrangement of the habitat) influences the lobsters' choice of it as a habitat and that lobster density may be proportional to the perimeter-to-area relationship of a patch (Fig. 5).

In the Gulf of Maine, the green sea urchin Strongylocentrotus droebachiensis is the largest herbivore. The destructive grazing potential of this species is well known (Breen \& Mann 1976, Chapman 1981), and a strong inverse correlation has been demonstrated between urchin and kelp abundance (Mann 1977 , Johnson \& Mann 1988). Since patch edge may be a limiting or restricting factor for determining lobster abundance within kelp beds, partial loss of kelp beds where gaps form could contribute to higher local densities. Our results suggest that small patchy kelp beds with a high perimeter-to-area relationship may represent a higher-quality habitat for lobsters, and that any factors influencing kelp patch size may then influence the local lobster population. Thus the local carrying capacity for lobsters may be maximal at some intermediate kelp cover condition, with lower lobster abundances when kelp cover is complete and lower still when kelp is absent.

It is possible that lobsters use edges of kelp beds to maximize their sensory input, while still allowing them to remain under cover. A lobser's visual and most chemical and mechanical receptors are located anteriorly, and lobsters occupying the perimeter were typically found facing out from the patch and often gave a meral (aggressive) spread of their chelae when approached. This type of behavior suggests that they are aware of the presence of others and is often associated with competitive interactions (Cobb 1971, O'Neill $\&$ Cobb 1979). Thus it is possible that the lobsters' edge-dwelling behavior satisfies their shelter-dwelling tendencies while allowing them to remain vigilant with respect to predators and inter-and intraspecific encounters. In theory, there could be a fractal geometry to kelp bed shape that would maximize local population densities (e.g. Caddy 1986). The optimum perimeter habitat would allow lobsters to occupy a region 
in the kelp bed just outside the range of detection of neighboring lobsters.

The carrying capacity for an organism in an environment is related to, among other things, the availability of habitat. For the American lobster, shelter availability may be a limiting factor in controlling the local population densities (Cobb 1971, Cooper \& Uzmann 1980). However, it is important to differentiate between factors that influence the entire population of a species, such as recruitment, and those that merely concentrate individuals, such as shelter availability. Concentrating factors in the environment may affect the local carrying capacity for an organism, while not necessarily changing the total carrying capacity for the population. Because complex macroalgal-covered boulders (Hudon \& Lamarche 1989), and more specifically kelp (this study), are habitats for the American lobster, changes in the abundance of kelp could influence the distribution of local lobster populations. If losses of kelp beds mean habitat loss for lobsters, then local lobster populations may decrease in abundance without significant changes in the entire population. These changes could, however, have important consequences for the local lobster fishery or potential prey species.

Acknowledgements. We thank R. J. Miller and R. A. Wahle for their careful review of and suggested improvements for this manuscript. We also thank B. Vadas, B. Glanz, and B. McAlice for their discussions and assistance in this project and helpful comments on earlier drafts. David O. Duggins gave us detailed instructions on making artificial kelp. A number of individuals aided us in the field including: W. Malpass, J. Ostozeski, T Miller, M. Graham, J. Fay, T. Lynn, and J. Beam, to all we are grateful. Funding for this research was primarily provided from NOAA via the University of Maine Sea Grant Program (NA86AA-D-SG047) with additional funds from the National Undersea Research Center, University of Connecticut at Avery Point, Maine Aquaculture Innovation Center, the University of Maine Association of Graduate Students and the Center for Marine Studies. All research was conducted at the University of Maine's Darling Marine Center. This is contribution \#262 from the Darling Marine Center

\section{LITERATURE CITED}

Allen, J. C., Griffiths, C. L. (1981). The fauna and flora of a kelp bed canopy. S. Afr. J. Zool. 16: 80-84

Bernstein, B. B., Mann, K. H. (1982). Changes in the nearshore ecosystem of the Atlantic coast of Nova Scotia, 1968-1981. NW Atlant. Fish. Org. Scient. Counc. Stud. 5: $101-105$

Bodkin, J. L. \{1988\}. Effects of kelp forest removal on associated fish assemblages in central California. J exp. mar. Biol. Ecol. 117: 227-238

Breen, P. A., Mann, K. H. (1976). Changing lobster abundance and the destruction of kelp beds by sea urchins. Mar. Biol. 34: $137-142$

Caddy, J. (1986). Modelling stock-recruitment processes in Crustacea: some practical and theoretical perspectives Can. J. Fish. Aquat. Sci. 42: 229-238
Carr, M. H. (1989). Effects of macroalgal assemblages on the recruitment of temperate zone reef fishes. J. exp. mar. Biol. Ecol. 126: 59-76

Chapman, A. R. O. (1981). Stability of sea urchin dominated barren grounds following destructive grazing of kelp in St. Margaret's Bay, Eastern Canada. Mar. Biol. 62: $307-311$

Cobb, J. S. (1971). The shelter related behavior of the lobster, Homarus americanus. Ecology 52: 108-115

Connell, S. D., Jones, G. P. (1991). The influence of habitat complexity on postrecruitment processes in a temperate reef fish population. J exp. mar Biol. Ecol. 151. $271-294$

Cooper, R. A., Uzmann, J. R. (1980). Ecology of juvenile and adult Homarus. In: Cobb, J. S., Phillips, B. F. (eds.) The biology and management of lobsters, Vol. II. Academic Press, New York, p. 97-142

Cowen, R., Agegian, C., Foster, M. (1982). The maintenance of community structure in a central California giant kelp forest. J. exp. mar. Biol. Ecol. 64: 189-201

DeMartini, E. E., Roberts, D. A. (1990). Effects of giant kelp (Macrocystis) on the density and abundance of fishes in a cobble-bottom kelp forest. Bull. mar. Sci. 46: 287-300

Ebeling, A. W., Laur, D. R. (1985). The influence of plant cover on surfperch abundance at an offshore temperate reef. Environ. Biol. Fish. 12: 169-179

Hacker, S. D., Steneck, R. S. (1990). Habitat architecture and the abundance and body-size-dependent habitat selection of a phytal amphipod. Ecology 71: 2269-2285

Hagen, N. T (1983). Destructive grazing of kelp beds by sea urchins in Vestfjorden, northern Norway. Sarsia 68 $177-190$

Heck, K. L., Orth, R. J. (1980). Seagrass habitats: the role of habitat complexity, competition and predation in structuring associated fish and motile macroinvertebrate assemblages. In: Kennedy, V. S. (ed.) Estuarine perspectives. Academic Press, New York, p. 449-464

Heck, K. L., Thoman, T A. (1981). Experiments on predatorprey interactions in vegetated aquatic habitats. $\mathrm{J}$. exp. mar. Biol. Ecol. 53: 125-134

Herrnkind, W. F., Butler, M. J. (1986). Factors regulating post larval settlement and juvenile microhabitat use by spiny lobsters, Panulirus argus. Mar Ecol. Prog. Ser. 34: $23-30$

Howard, A. E. (1980). Substrate controls on the size composition of lobster (Homarus gammarus) populations. J. Cons. int. Explor. Mer 39: 130-133

Hudon, C. (1987). Ecology and growth of post-larval and juvenile lobster, Homarus americanus, of Isle de la Madeleine (Quebec). Can. J. Fish. Aquat. Sc1. 44: 1855-1869

Hudon, C., Lamarche, G. (1989). Niche segregation between American lobster Homarus americanus and rock crab Cancer irroratus. Mar. Ecol. Prog. Ser. 52: 155-168

Johnson, C. R., Mann, K. H. (1988). Diversity, patterns of adaptation, and stability of Nova Scotian kelp beds. Ecol. Monogr. 58: 129-154

Kikuchi, T (1980). Faunal relationships in temperate seagrass beds. In: Phillips, R. C, McRoy, C. P. (eds.) Handbook of seagrass biology: an ecosystem perspective. Garland STPM Press, New York, p. 153-172

Littler, M., Martz, D., Littler, D. (1983). Effects of recurrent sand deposition on rocky intertidal organisms: importance of substrate heterogeneity in a fluctuating environment. Mar. Ecol. Prog. Ser 11:129-139

Luckhurst, B. E., Luckhurst, K. (1978). Analysis of the influence of substrate variables on coral reef fish communities. Mar. Biol. 49: 317-323 
Mann, K. H. (1977). Destruction of kelp-beds by sea urchins: a cyclical phenomenon or irreversible degradation? Helgoländer wiss. Meeresunters. 30: 455-467

Marx, J. M., Herrnkind, W. F. (1985) Macroalgae (Rhodophyta: Laurencia spp.) as habitat for young juvenile spiny lobsters, Panulirus argus. Bull. mar. Sci. 36: 423-431

Miller, R. J. (1989). Catchability of American lobsters (Homarus americanus) and rock crabs (Cancer irroratus) by traps. Can. J. Fish. Aquat. Sci. 46: 1652-1.657

O'Neill, D. J., Cobb, J. S. (1979). Some factors influencing the outcome of shelter competition in lobsters (Homarus americanus). Mar. Behav. Physiol. 6: 33-45

Paine, R. T., Vadas, R. L. (1969). The effect of grazing by sea urchins, Strongylocentrotus spp., on benthic algal populations. Limnol. Oceanogr. 14: 710-719

Rasmussen, E. (1973). Systematics and ecology of the Isefjord marine fauna. Ophelia 11:1-495

Scheibling, R. (1986). Increased macroalgal abundance following mass mortalities of sea urchins (Strongylocentrotus droebachiensis) along the Atlantic coast of Nova Scotia Oecologia 68: 186-198

Schneider, F. I., Mann, K. H. (1991). Species specific relationships of invertebrates to vegetation in a seagrass bed. II Experiments on the importance of macrophyte shape, epiphyte cover and predation. J. exp. mar. Biol. Ecol. 145 $119-139$

This article was presented by C. Hudon, Halifax, N.S., Canada
Sousa, W. P. (1979). Disturbance in marine intertidal boulder fields: the nonequilibrium maintenance of species diversity. Ecology 60: 1225-1239

Stoner, A. W., Lewis, F. G. (1985). The influence of quantitative and qualitative aspects of habitat complexity in tropical sea-grass meadows. J exp. mar. Biol. Ecol. 94: 19-40

Thomas, J. C. (1973). Analysis of the commercial lobster (Homarus americanus) fishery along the coast of Maine, August 1966 through December 1970. NOAA Tech. Rep. NMFS SSRF 667

Virnstein, R. W., Curran, M. C. (1986). Colonization of artificial seagrass versus time and distance from source. Mar. Ecol. Prog. Ser. 29: 279-288

Wahle, R. A., Steneck, R. S. (1991). Recruitment habitats and nursery grounds of the American lobster Homarus americanus: a demographic bottleneck?. Mar. Ecol. Prog. Ser. 69: $231-243$

Wahle, R. A., Steneck, R. S. (1992). Habitat restrictions in early benthic life: experiments on habitat selection and in situ predation with the American lobster. J. exp. mar. Biol. Ecol. 157: 91-114

Wharton, W. G., Mann, K. H. (1981). Relationship between destructive grazing by the sea urchin, Strongylocentrotus droebachiensis and the abundance of American lobster, Homarus americanus, on the Atlantic coast of Nova Scotia. Can. J. Fish. Aquat. Sci. 38: 1339-1349

Manuscript first received: November 25, 1992

Revised version accepted: June 10,1993 